\title{
ARADUS OROSZI SP. N. FROM TAIWAN (HEMIPTERA, HETEROPTERA, ARADIDAE)
}

\author{
TAMÁs VÁSÁRHELYI \\ Department of Zoology, Hungarian Natural History Museum \\ H-1088 Budapest, Baross u. 13, Hungary, E-mail: vasarhelyi@nhmus.hu
}

Aradus oroszi sp. n. (Heteroptera, Aradidae, Aradinae) is described and illustrated from Taiwan.

Key words: Aradinae, Aradus, new species.

\section{INTRODUCTION}

Due to collecting activity of Hungarian lepidopterists in Taiwan (RoNKAY et al. 2013) a small but valuable aradid material has accumulated in the Hungarian Natural History Museum, Budapest, from which one new species is described in the present paper. HeIss (2009) pointed out that a revision of Miraradus Vásárhelyi, 1980 would be necessary. This paper is not intended to clarify the relationship between the genera Aradus Fabricius, 1803 and Mirara$d u s$, obviously needing further investigation, but the new species is placed into the East Palaearctic orientalis-compar species group of the genus Aradus following Heiss (2003).

\section{MATERIAL AND METHODS}

The single studied specimen was mounted on card (unfortunately too strongly to be removed without risk of damage therefore ventral side could only partially be studied). Drawings were made with an Opton 475052 - 9901 microscope supported with drawing apparatus.

\section{Aradus oroszi sp. $n$.}

(Figs 1-6)

Diagnosis - In the key to the East Palaearctic A. orientalis-compar species group (Heiss 2003) it runs to A. yunnanus Heiss, 2003, but abdomen is much narrower, and the ratio of antennal joints is different, unique in this species group.

Description - Female, macropterous, brown with characteristic yellow coloration (Figs 1-5). Head about as long as wide across eyes. Antenniferous tubercles pointed, di- 


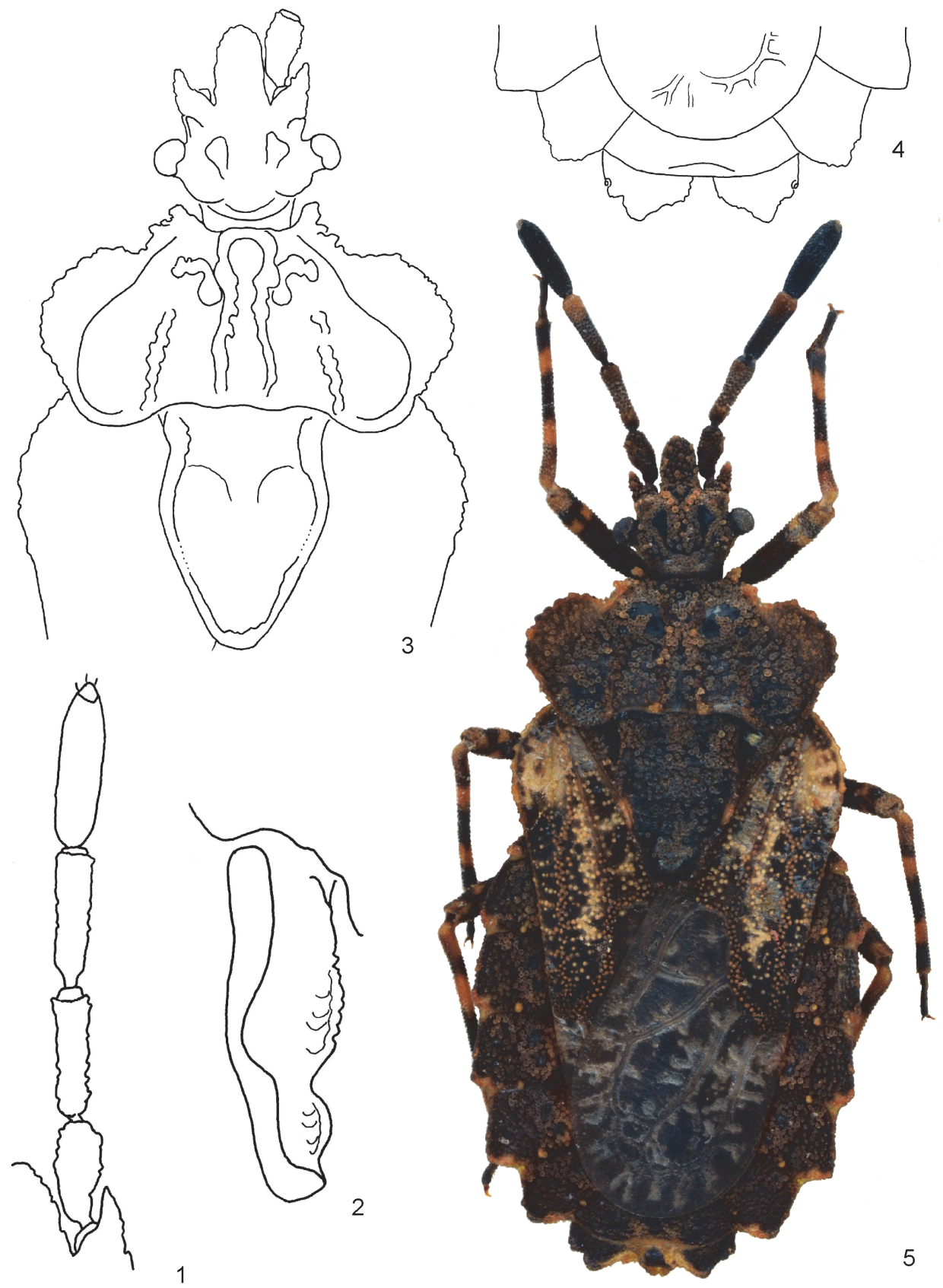

Figs 1-5. Aradus oroszi sp. n., holotype, female: $1=$ antenna, $2=$ scutellum, dorsolateral view, 3 = head, pronotum and scutellum, $4=$ tip of abdomen, $5=$ habitus. 
rected anteriad, with large dorsal tooth. Eyes protruding, semipedunculate. Postocular tubercle flat, with granulation. Antennae long, 2 times as long as width of head; joint I surpassing clypeus; II and III slightly thickened apically, dorsal side of the latter yellow in its apical 2/5; joint IV longest. Relative lengths of antennal joints I to IV as $27: 33: 34: 40$.

Pronotum 2.4 times wider than long, with dorsolaterally extended lateral margins (paranota), their margin irregularly dentate especially at anterolateral section. Disc with 4 low carinae, lateral ones converging anteriorly, mesal ones elevating in anterior third. Anterolateral notch of pronotum similar to that of A. yunnanus, anterior margin yellow. Hemelytra with pale yellow patch near basis, yellowish coloration running along cubitus, granules partly pale brown or yellowish.

Scutellum with concave anterolateral borders, almost 1.5 times as long as wide. Lateral margin elevated except near apex (Fig. 2).

Legs slender, with yellow rings at the apical part of femora and the basal and apical parts of tibiae. Femorotibial articulations pale yellowish. Trochanter and femur fused on legs I and II, separated by distinct suture on III.

Abdomen with laterally extended dorsal external laterotergites (Deltg) on segments II-VIII, margin of VII-VIII acute-angled, each with a protruding tooth, margins of posterolateral angles yellow. Spiracles ventral, lateral on Deltg VIII, before pointed tooth.

Measurements - Total length (female) $7.69 \mathrm{~mm}$, length of head $1.34 \mathrm{~mm}$, width of head $1.29 \mathrm{~mm}$, length of pronotum $1.16 \mathrm{~mm}$, width of pronotum $2.72 \mathrm{~mm}$, length of scutellum $1.59 \mathrm{~mm}$, width of scutellum $1.09 \mathrm{~mm}$, with of abdomen across segment V $3.41 \mathrm{~mm}$.

Discussion - The availability of a single female usually makes authors cautious in preparing a description. The characteristic antennal joint IV being the longest is, however, unique within the species group and justifies the proposal of a new species. Allometric growth of antennal joints showed, that longest joint IV is characteristic of young larvae in Aradidae usually until instar IV or V (VÁsÁrhelyi 1985). There seems to be a trend in the species of the Oriental and East Palaearctic A. orientalis-compar species group, in the subgenus Lobataradus Heiss, 2008 proposed for species showing phylogenetical relationship to this species group (HeIss 2008), and also in the related genus Miraradus (originally described as subgenus of Aradus) towards stronger lateral development of lateral body portions, and an expressed diversification of antennal joint development (resulting also in length of joints, joint IV being remarkably short in Lobataradus). A. oroszi having longest joint IV (obviously a secondary and not neotaenic feature) is therefore an important species in understanding evolutionary patterns in these taxa.

Type material - Holotype, female: TAIWAN, Taichung CO., 2200 m, Pilushi, TFRI site, 26-28. 12. 2001, leg L. Ronkay \& A. Kun. Deposited in the Hungarian Natural History Museum, Budapest.

Habitat - The specimen was found at the meteorological station of Taiwan Forestry Research Institute, which is located on the bottom of a deep and narrow valley, surrounded by deciduous forests. The collector, L. Ronkay informed me that the specimen was collected on a fallen trunk of Abies kawakamii (Hayata) T. Itô (Pinaceae) (Fig. 6). 


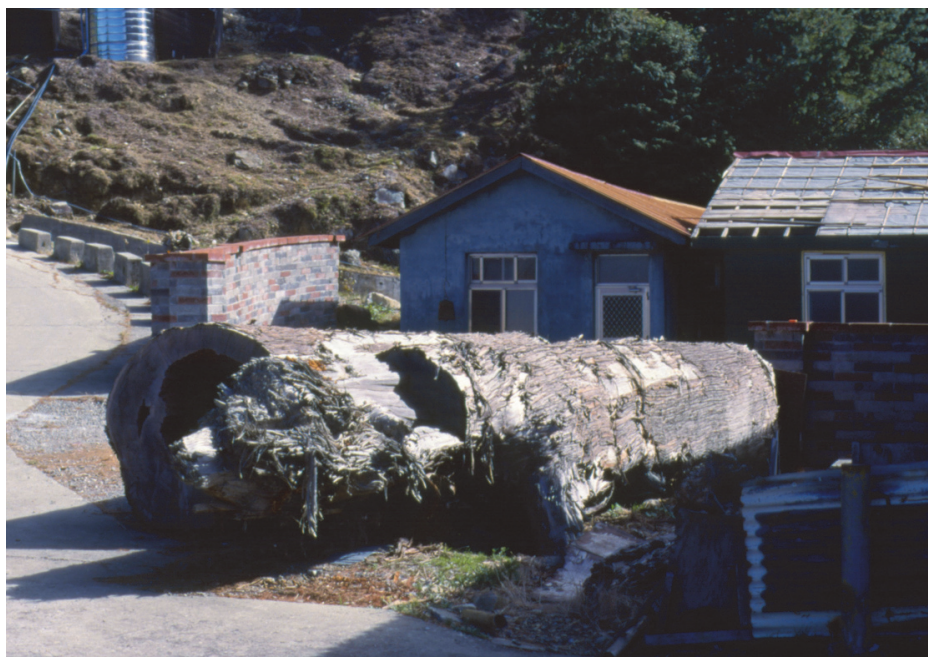

Fig. 6. The collecting site of Aradus oroszi sp. $\mathrm{n}$.

Etymology - The species is dedicated to Mr. András Orosz, originally an electronic engineer, a friend and staff member of the Hemiptera Collection of the Hungarian Natural History Museum since the early 1990s, now an excellent scholar of Auchenorrhyncha, to commemorate his 80th birthday.

Acknowledgements - The author is much indebted to Dr. László Ronkay for providing detailed information on the type locality, and Tamás Németh for preparing the photograph of the specimen.

\section{REFERENCES}

HeIss, E. (2003) A review of the east Palaearctic Aradus orientalis - compar group, with descriptions of two new species (Heteroptera, Aradidae). Zeitschrift der Arbeitsgemeinschaft Österreichischer Entomologen 55: 9-26.

Heiss, E. (2008) Aradus dembickyi sp. n. from Northern India (Insecta: Heteroptera: Aradidae). Annalen des Naturhistorischen Museums Wien, series B 109: 77-81.

Heiss, E. (2009) Two new Aradidae from Taiwan (Hemiptera: Heteroptera: Aradidae). Zeitschrift der Arbeitsgemeinschaft Österreichischer Entomologen 61: 89-94.

Ronkay G., Ronkay L., László M. Gy., Fu, Chien-Ming \& Wu, Shiper (2013) The atlas of the Noctuidae (s.l.) fauna of Taiwan (Lepidoptera, Noctuoidea). Part I. Noctuidae: Noctuinae and Plusiinae. Fibigeriana Supplement. Book Series of Taxonomy and Faunistics. Volume 1. Heterocera Press, Budapest, pp. 9-122.

VÁsÁRHELYI, T. (1985) Investigations on the allometric growth of Aradus species (Heteroptera, Aradidae). Annales historico-naturales Musei nationalis hungarici 77: 145-151.

Received February 3, 2016, accepted March 29, 2016, published May 6, 2016 